\title{
Time Management of Educational Inspectors
}

\author{
Süleyman Göksoy \\ Correspondence: Assist. Prof. Dr. Süleyman Göksoy, Düzce University Faculty of Education, Educational Sciences \\ Educational Adminidtration and Supervision, Turkey
}

Received: August 3, 2015 Accepted: August 11, $2015 \quad$ Online Published: September 29, 2015

doi:10.11114/jets.v3i6.1108

URL: http://dx.doi.org/10.11114/jets.v3i6.1108

\begin{abstract}
The aim of the research is to determine the fields that Educational Inspectors have to spare time for and the fields that Educational Inspectors demand to make time for. The data collected by review form was analyzed by content analysis method. According to research results: Educational Inspectors want to make time mostly for counselling and research activities, educational seminars, in-service training activities, projects, post graduate education and domestic/outland trips. They believe that they will be more successful in this way. The following suggestios are developed based on research results: Domestic and outland seminars, courses, trips and observation opportunities should be provided for personal developments of educational inspectors. In an educational organization, educational leadership roles of Educational Inspectors should be enhanced instead of their rutin bureaucratic works and activities and their roles (inspection, document tracking, monitoring legistation) in parallel with these works. Educational Inspectors should be provided with more transportation convenience and technologic opportunities should be increased.
\end{abstract}

Keywords: time management, educational inspectors

\section{Introduction}

Time is a limited source that cannot be renewed (Drucker, 2007), a needed process to finish a work (Çelik, 2002), a value that should be planned and managed and a never-ending process that continues out of individuals' control and happens from past to present (Smith, 1998). Researches have revealed that managers' tendency to maintain their organizational position increases based on the raise on management pyramid (Usta, 2001). It is emphasized that there is a positive relationship between effective usage of time and planning and organization in conducted researches (Kelly\&Johnson, 2005). Efficiency in production increases and quality improves when time is used efficiently (Atay, 1999). Complications, timesinks and wastages in businesses are preveted by using time efficiently and effectively (Aydeniz, 2000). Using time effectively in working environment reduces the pressure of workload and contibutes to success (Gönen \& Özmete, 2004).

The principle of using time effectively and efficiently is good management. Reaching out the organizational effectiveness which is the degree of accomplishing the goals is only possible with effective time management (Danielson, 1963). Time management means planning the activities of our goals, purposes, social lives and pleasures in a way that we can carry out most beneficially (Yavaş et al. 2012). It is a process that an individual implements the management functions (planning, organizing, instruction, coordination and controlling) into his own actions in order to reach his personal and vacational goals effectively and efficiently. It has become one of the most crucial factors of success in professional working life (Koch, 1998). It means productive usage of resources (Yilmaz \& Aslan, 2002).

Time management has become an important term, a subject and a management mentality in literature of management science and public management in recent years. This is because time is undeniably one of the most crucial resources for management and managers. When time is managed effectively, organization and management will become more productive and ineffectiveness problem will dissappear (Aydin, 2011). Briefly, as long as time is managed beneficially, main functions of management (planning, organizing, management, coordination and inspection) can be carried out in the right way (Aydın, 2011). The aim of time management is to help individuals and especially managers use their time effectively and efficiently. Using or managing time effectively means planning every hour, every minute according to a specific aim and purpose (Uğur, 2000).

The aim of time management is to help individuals and especially managers use their time effectively and efficiently (Karaoğlan, 2006; Ardıç 2010). It demonstrates that there are meaningful and positive relationships between leadership degree and time management level. In order to gain productivity and to acquire advanced service, it is important to 
focus on doing better in short period rather than maintaining the better work in quality leadership (Çelik, 2013).

Effective time usage is a must for individual and organizational success and productivity. Conducted researches have pointed out that positive time management applications have positive effect on job satisfaction and organizational performance (Lim, 1993; Landy et al. 1991). However, according to some research results, time management problems among teachers, nurses, managers and students are experienced intensely (Koch \& Kleinmann, 2002). Luthans, Yodgetts and Rosenkrantz (1988) separated effectiveness and success in managers and it was seen that effective managers and successful managers use their time differently. While the most effective managers spared a great deal of their time on communication and human resources management, they spent relatively less time on networking (socializing, policy making, building relations with external stakeholders). On the other hand, successful managers spared nearly the half of their time on networking (socializing, policy making, building relations with external stakeholders) and they spent only ten percent of their time on human relations management (activities related to human such as motivation, discipline, education, staffing) (Bolman \& Deal, 2013).

In Turkey, Educational Inspectors presidency was established with delegated legislation numbered 652 about organization and function of Ministry of National Education, the law number 6528 and Regulations of counselling and inspection presidency and educational inspections presidency. Educational Inspections presidencies carry out the evaluations of activity processes and results of every institutions and establishments which are under the inspection of presidency. Also they perform counselling, inspection and investigation-examination of the administrative, financial and legal transactions of these institutions and establishments. (Presidency of National Education, 2014)

Educational Inspectors who are managers and auditors must use their time effectively and efficiently. The aim of the research is to determine the fields that educational inspectors have to spare time for and the fields that Educational Inspectors demand to make time for. For this purpose, 18 Educational Inspectors working in Istanbul and Bolu were chosen with purposeful sampling method and they were implemented semi-structured interview forms. The results were evaluated.

\section{Method}

\subsection{Research Method}

This research aims to determine the views of Educational Inspectors about the effective usage of their time. It is a descriptive study to determine the situation. Qualitative research method was used in the research. According to Yıldırım and Şimşek (2005), qualitative research is a research method that examines the process in which data analysis techniques such as interview and document analysis are used and events are performed realistically and holiscticly in a natural environment.

\subsection{Working Group}

The working group of the research is determined based on purposeful sampling method. Purposeful sampling method enables in-depth investigation of the contentful situations (Yıldırım and Şimşek, 2005).

For this purpose, 18 Educational Inspectors who work in İstanbul and Bolu in 2014-2015 academic year are determined as participants. Semi-structured interview form developed by researchers was used in the research. Educational Inspectors of the working group was requested to state how they vocationally use their time in the scope of institutionally effective time management. Educational Inspectors who are volunteer in this study are posed three open ended questions. Information about the participants is given in Table 1.

Information about the working group is given in Table 1.

Table 1. Personal Information about the Educational Inspectors

\begin{tabular}{llcc}
\hline & Variable & f & \% \\
\hline \multirow{4}{*}{ Gender } & Female & 4 & 22 \\
& Male & 14 & 78 \\
\multirow{4}{*}{ Age } & $20-30$ & - & - \\
& $31-40$ & 2 & 11 \\
& $41-50$ & 11 & 61 \\
& 50 and above & 5 & 28 \\
\hline
\end{tabular}

According to Table 1, there are 14 male respondents and 4 fenale respndents. Most of the inspectors are between the age of 41-50 $(n=11)$. However, participation of inspectors from different age groups is given importance.

\subsection{Data Collection Tool}

Research data were collected by a semi structured interview form prepared in accordance with the open ended question technique. This standard and flexible form provides extensive data collection, enables participants to express their 
opinions easily and eases the process of data collection/analysis (Y1ldırım and Şimşek, 2005; Balc1, 2009). Related literature was scanned, open ended questions were prepared, two domain experts were consulted in order to provide internal validity and participant confirmation to give response to the questions was provided while preparing the form. Two experts in the field of educational sciences were consulted in order to provide content validity. Two heads of Educational Inspectors an one co-head of Educational Inspectors who are out of the working group were interviewed and content adequacy was controlled. After some conceptual adjustments, interview form was put into final form. Obtained data were compared to literature and legislation in order to check the correctness. The form was put into ultimate form and distributed to the inspectors for application. Accordingly, the following questions were asked to educational inspectors:

1. Do you use your time effectively and efficiently considering the current inspection system and your inspection experiences?

2. How do you use most of your time considering the current inspection system and your inspection experiences? On which works? Why?

3. On which works do you wish to spend your time considering the current inspection system and your inspection experiences? Why?

\subsection{Data Analysis and Interpretation}

The data were analysed by content analysis techniques. Similar data are collected in terms of particular terms and themes in order to reach some concepts and relations which can explain the collected data in content analysis (Yildırım and Şimşek, 2008). Accordingly, similar data were gathered in terms of particular terms and themes. After they were organized in a way that readers can understand, they were interpreted. Views were placed in themes considering the similarities, differences and relationships of the interpretations. Views of participants were quoted without making any change. Obtained findings were interpreted in accordance with theoric information. Participant inspectors were represented with abbreviations (EI1, EI2, EI18) in order to provide privacy and each participant was given a number.

\section{Findings and Interpretations}

Reseach results were presented in tables and they were interpreted. Opinions of inspectors about their vocationally effective/efficient usage of time are presented in Table 2.

Table 2. Opinions about effective usage of time

\begin{tabular}{llc}
\hline Opinion of Participant & \multicolumn{1}{c}{ Participant } & f \\
\hline I cannot use & EI5, EI6, EI7, EI8, EI9, EI10, EI11, & 14 \\
& EI12, EI13, EI14, EI15, EI16, EI17, & \\
I can use & EI18 & 4 \\
\hline
\end{tabular}

While a large part of Educational Inspectors ( $\mathrm{f}=14$ ) think that that cannot use their time effectively, a small part of them $(\mathrm{f}=4)$ state that they can use their time effectively according to Table 1 . Some of the statements of Educational Inspectors are given below.

Educational Inspectors who think that they cannot use their time effectively stated, "No. Our workload causes us to spend our free time doing some work." (EI6, 7, 9, 13, 14, 16, 17, 18), "What have been planned is not always performed." (EI8), "I can use my time effectively on investigations but it is not the same with inspections." (EI11). Those who stated that thay can use their time effectively stated, "I use my time effectively since I am in the management staff." (EI1), "I try to use my time in the most effective way for different type of works." (EI3), "I try to do my job ideally in order to accomplish the responsibilities that are given to educational inspectors" (EI4). These statements demonstrates that most of the Educational Inspectors who work in upper management-inspection field think that they cannot use their time effectively and efficiently.

Opinions of Educational Inspectors about the works and businesses that they spare most of their time for are given in Table 3. 
Table 3.Opinions about the works and businesses that Educational Inspectors spare most of their time for

\begin{tabular}{|c|c|c|}
\hline Theme & Participant & f \\
\hline $\begin{array}{l}\text { Investigation-examination and } \\
\text { their reports }\end{array}$ & $\begin{array}{l}\text { EI1, EI2, EI3, EI4, EI5, EI6, EI7, EI8, } \\
\text { EI9, EI10, EI11, EI12, EI13, EI14, EI15, } \\
\text { EI16, EI17, EI18 }\end{array}$ & 18 \\
\hline Traffic and transportation & $\begin{array}{l}\text { EI8, EI9, EI10, EI11, EI12, EI13, EI14, } \\
\text { EI15, EI16, EI17, EI18 }\end{array}$ & 12 \\
\hline $\begin{array}{l}\text { Rutin bureaucratic things, } \\
\text { document analysing, document } \\
\text { tracking }\end{array}$ & $\begin{array}{l}\text { EI1, EI3, EI6, EI7, EI8, EI9, EI10, EI11, } \\
\text { EI12, EI13, EI15, EI18 }\end{array}$ & 12 \\
\hline $\begin{array}{l}\text { Tracking the changes in } \\
\text { legislation and programmes }\end{array}$ & $\begin{array}{l}\text { EI4, EI6, EI8, EI9, EI10, EI11, EI14, } \\
\text { EI13, EI15 }\end{array}$ & 9 \\
\hline $\begin{array}{l}\text { Institutional inspection and } \\
\text { counselling works- especially } \\
\text { impractical and nun-functional } \\
\text { inspection forms }\end{array}$ & EI2, EI6, EI7, EI11, & 4 \\
\hline Private educational institutions & EI17, & 1 \\
\hline
\end{tabular}

According to Table 3, the works and businesses that Educational Inspectors have to spent time on are investigation-examination and their reports $(\mathrm{f}=18)$, traffic and transportation $(\mathrm{f}=12)$, rutin bureaucratic things, document analysing, document tracking ( $\mathrm{f}=12$ ), Tracking the changes in legislation and programmes ( $\mathrm{f}=9$ ), Institutional inspection and counselling works- especially impractical and nun-functional inspection forms $(\mathrm{f}=4)$ and private educational institutions $(\mathrm{n}=1)$. Some significant views of inspectors on this subject are as follows:

EI15 "I spend most of my time in traffic and it is very tiresome. Also writing reports takes a great deal of my time since I am an investigation staff member", EI16 "I have to spend so much time in traffic in Istanbul. Investigation, examination documents are very intensive.", EI4 "I spend my time on tracking tha changes in legislation and programmes, carrying out investigations and examinations and writing reports.", EI7 "Investigation, examinetion, inspection, counselling.", EI11 "Rutin things like document analysing takes the most of out time.", I12 "Rutin processes in inspection, writing reports and time spent in traffic...", EI18 "I spend my time mostly in traffic in Istanbul. Also document tracking takes my time."

Opinions of Educational Inspectors about the works and businesses that they want to spend their time on are presented in Table 4.

Table 4. Opinions of inspectors about the works and businesses that they want to spent most of their time on

\begin{tabular}{|c|c|c|}
\hline Theme & Participant & $\mathbf{f}$ \\
\hline Counselling and investigation & $\begin{array}{l}\text { EI1, EI2 ,EI3, EI4, EI5, EI7, } \\
\text { EI8, EI9, EI10 EI11, EI12, } \\
\text { EI13, EI14, EI15, EI16, EI17, } \\
\text { EI18 }\end{array}$ & 17 \\
\hline Educational seminars, in-service training activities & $\begin{array}{l}\text { EI3, EI6, EI7, EI8, EI9, EI10, } \\
\text { EI11, EI15, EI17 }\end{array}$ & 9 \\
\hline Projects & EI6, EI7, EI11, EI12 & 4 \\
\hline Post graduate education & EI10, EI11, EI13, EI15 & 4 \\
\hline Domestic and outland trips & EI3, EI6, EI9, EI13 & 4 \\
\hline
\end{tabular}

According to Table 3, vocational activities that inspectors want to spent most of their time on are as follows: counselling and investigation ( $\mathrm{f}=17)$, educational seminars, in-service training activities $(\mathrm{f}=9)$, projects $(\mathrm{f}=4)$, post graduate education $(\mathrm{f}=4)$, and domestic and outland trips $(\mathrm{n}=4)$. Some significant opinions of inspectiors are given below:

EI1 "I wish school managers were informed about management and teachers were developed in classroom management.", EI12 "I wish I could participate in projects about applying education to every part of life.", EI6 "I would investigate educational and inspection systems of developed countries and I would try to spread the positive detections in my country.", EI7 "Counselling, being an educator (in a seminar or a course), project development, on-the-job teaching", EI10 "I wish I was given enough time to spent on counselling along with inspection.", EI13 "Research and development, self-perpetuation, vocational foreign trips, post graduate education and doctorate", EI15 "I would spend most of my time on counselling and giving lessons in in-service training activities. Also I would participate in vocational development activities that can help me improve myself."

\section{Result and Debate}

In the result of the research that was aimed to determine the fields that Educational Inspectors vocationally have to spend time for and the fields that they want to spend time for, it is indicated that most of the Educational Inspectors think that they cannot use their time effectively and efficiently. 
The works and businesses that Educational Inspectors have to spend most of their time for are investigation-examination and their reports, traffic and transportation, rutin bureaucratic things, document analysing, document tracking, tracking the changes in legislation and programmes, institutional inspection and counselling worksespecially impractical and nun-functional inspection forms and private educational institutions.

Based on research results, Educational Inspectors want to spare most of their time on counselling and investigations, educational seminars, in-service training activities, projects, post graduate education, domestic and outland trips. They believe that they will be more successful in this way.

The results are parallel with the research about low and medium level managers carried out by Luthans (1988). In Luthans' studies, it is pointed out that low and medium level managers spend \%60 of their time doing "constructive activities" (traditional management functions such as rutin works, planning and controlling-inspection), they use $\% 20$ of their time for "management of human resources" (motivation, discipline, education, staffing) and they spend nearly \%20 of their time on networking (socializing, policy making, constructing relationships with external stakeholders). In this case, as Kotter and Lynn (1992) have mentioned, middle level managers spend more time on difficulties and less time on rutin works compared to high level managers. (Bolman \& Deal, 2013).

\section{Suggestions}

The following suggestions are developed based on the results of this research which was about effective and successful time management of educational inspectors.

a. Domestic and outland seminars, courses, trips and observation opportinities should be arranged for personal development of educational inspectors.

b. Instead of rutin breaucratic works and related roles (inspection, document tracking, legislation tracking etc.), educational leadership roles of Educational Inspectors should be highlighted in an educational organization.

c. Educational Inspectors should be provided with more transportation convenience and technologic opportunities should be increased.

d. Works to do in order to provide effective usage of material and human resources in the process of management and inspection in an educational organization should be planned according to priorities and urgencies.

\section{References}

Ardıç, C. (2010). Zaman yönetimi ve zaman yönetiminde dönüştürücü liderlerin davranışlarını belirlemeye yönelik bir araştırma. Gazi Üniversitesi, Sosyal Bilimler Enstitüsü, Yayınlanmamış Yüksek Lisans Tezi, Ankara.

Atay, O. (1999). Örgütlerde zaman yönetimi ve kahramanmaraş tekstil sanayinde bir uygulama. Celal Bayar Üniversitesi İktisadi ve İdari Bilimler Fakültesi Dergisi, Sayı:5, Y1l: ss. 63-73.

Aydeniz, N. (2000). Zaman yönetimi açısından diyarbakır kamu ve özel sektöründe verimli ve etkin zaman kullanımı araştırması. Celal Bayar Üniversitesi İktisadi Ve İdari Bilimler Fakültesi Dergisi, Sayı: 6.

Aydın, A. H. (2011). Yönetim bilimi, 4. Baskı, Seçkin Yayıncılık, Ankara.

Balc1, A. (2009). Sosyal bilimlerde araştırma (7. baskı). Ankara: Pegem A Yayıncılık.

Bolman, L. G., \& ve Deal, E., T. (2013). Organizasyonları Yeniden Yapılandırmak (Çeviri Editörleri: Ahmet Aypay, Abdurrahman Tanrı̈̈̆gen). Seçkin yayınları, 4. Baskı.

Çelik, V. (2002). Sınıf yönetimi. Ankara: Nobel Yayıncılık.

Çelik, V. (2013). Eğitimsel liderlik, Pegem A akademi, 7. Baskı. Ankara.

Danielson, L., E. (1963). Management of time. Management of Personnel Quarterly, 2(1).

Drucker, P. (2007). Etkin yöneticilerin seyir defteri. (Çev. Zülfü Dicleli). Optimist Yayınları.

Gönen, E., \& Özmete, E. (2004). Çalışma yaşamında zaman tuzaklarına ilişkin bir inceleme”, Standard Ekonomik ve Teknik Dergisi, 43, 507, Mart.

Karaoğlan, A. D. (2006). Üst düzey yöneticilerin zaman yönetimi. Balıkesir Üniversitesi Fen Bilimleri Enstitüsü. Yayınlanmamış Yüksek Lisans Tezi, Balıkesir.

Kelly, E., William, J., \& Judith, L. (2005). Time use efficiency and the five-factor model of personality. Education, 125(3), Year:Spring.

Koch, C. J., \& Kleinmann, M. (2002). A stitch in time saves nine: Behavioural decision Eğitimde Politika Analizleri ve Stratejik Araştırmalar Dergisi, Cilt 2, Sayı 1.

Koch, R., (1998). The 80/20 principle: the secret of achieving more with less, Bantam Doubleday Dell Publishing 
Group, New York.

Landy, F. J., Rastegary, H., Thayer, J., \& Colvin, C. (1991). Time urgency: The Construct and Its Measurement. Journal of Applied Psychology, 76,644-657. http://dx.doi.org/10.1037/0021-9010.76.5.644

Lim, Y. M. (1993). Time dimensions of work: relationships with perceived organizational performance. Journal of Business and Psychology, 8, 91-102. http://dx.doi.org/10.1007/BF02230395

Luthans, F., Yodgetts, R. M., \& Rosenkrantz, S. A. (1988). S. A. Real managers. Cambridge, Mass.:Ballinger.

Smith, H. W. (1998). Hayatı ve zamanı yönetmenin 10 doğal yasası, (Çeviren:Aslı Cıngıl Çelik), Rota Yayın Yapım Tanıtım, İstanbul.

Tengilimoğlu, D., Tutar, H., Altınöz, M., Öztürk Başpınar, N., \& Erdönmez, C. (2003). Zaman yönetimi, (Editör: Hasan Tutar), Nobet Yayın Dağıtım, Ankara.

Tutar, H. (2007). Zaman Yönetimi, Seçkin Yayıncılık, Ankara.

Usta, R. (2001). Zaman yönetimi ve yöneticilerin zamanı kullanma biçimleri”, Standard Ekonomik ve Teknik Dergisi, Y1l:40, Say1:478, Ekim, 75-80.

Yavaş, Ü., Öztürk, G., Açıkel, C. H., \& Özer, M. (2012). Tıp fakültesi öğrencilerinin zaman yönetimi becerilerinin değerlendirilmesi. Prev Med Bul; 11(1), 5-10.

Yıldırım, A., \& ve Şimşek, H. (2008). Sosyal bilimlerde nitel araştırma yöntemleri. Ankara: Seçkin Yayıncılık.

Yılmaz, A., \& Aslan, S. (2002). Örgütsel zaman yönetimi, Çukurova Üniversitesi, İktisadi ve İdari Bilimler Dergisi, Cilt 3, Say1 1 .

\section{$(\mathrm{cc}) \mathrm{BY}$}

This work is licensed under a Creative Commons Attribution 3.0 License. 